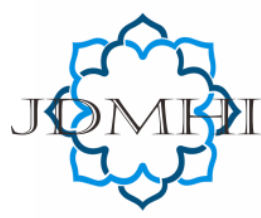

email: jdmhi@walisongo.ac.id

Journal of Digital Marketing and Halal Industry

ISSN: 2716-4810 (print) ISSN: 2716-4802 (online)

\title{
Policy Analysis of Enforcement of Halal Product Guarantee Regulations Through The Regulatory Impact Analysis (RIA) Approach
}

\author{
Hery Purwanto ${ }^{1}$, Sumunar Jati2 ${ }^{2}$, Ahmad Rofiq ${ }^{3}$ \\ ${ }^{1}$ Central Java Al-Qur'an Science University in Wonosobo, Indonesia \\ ${ }^{2}$ The Assessment Institute For Foods, Drugs, And Cosmetics, The Indonesian Council of Ulama \\ Islamic State University of Walisongo, Indonesia
}

\section{A R T I C LE I N F O}

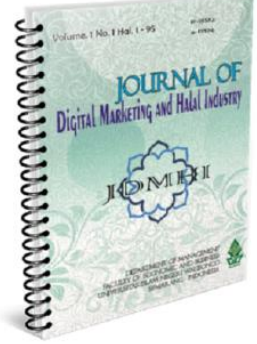

Article history:

Received 18 July 2021

Accepted 25 September 2021

Published 30 October 2021

Keywords:

Halal Product, Mandatory,

Regulatory Impact Analysis

(RIA)

\section{A B S T R A C T}

Halal products are products consumed by the community, especially Muslim communities. Given that Indonesia is a Muslim-majority country, the State handles the production and distribution of halal products. In 2019, the Ministry of Religion stipulated Regulation of the Minister of Religion of the Republic of Indonesia (PMA) Number 26 of 2019 concerning Guaranteed Halal Products. Therefore, enforcement of halal certification for products circulating in Indonesia is mandatory. However, regulation enforcement generally has many challenges to predict impacts without detailed studies and consultations with affected parties. In this regard, the purpose of this study is to analyze the impact of the application of PMA number 26 of 2019 compulsorily by using Regulatory Impact Analysis (RIA). This study concludes a gap between current conditions and ideal conditions that need to be postponed to enact the Regulation of the Minister of Religion of the Republic of Indonesia Number: 26 of 2019 by correcting the gap.

\section{Introduction}

The halalness of a product is a mandatory requirement for every consumer, especially Muslim consumers. Whether products like food, medicines, or other consumer goods. In line with many Muslim consumers in
@2021 Journal of Digital Marketing and Halal Industry Indonesia, which in 2020 reached 87.2 percent or 234.2 million, people (IBTimes.ID, 2020), the Indonesian market has become a big Muslim consumer market by itself. Therefore, guaranteeing halal products is an important thing to get the attention of the State. As stated in the

* Corresponding author. email: hepu@unsiq.ac.id DOI: http://dx.doi.org/10.21580/jdmhi.2021.3.2.9345 
Preamble of the 1945 Constitution of the Republic of Indonesia (UUD 1945), the State is obliged to protect the entire Indonesian nation and all Indonesian bloodshed and create public welfare.

In the current food industry, food ingredients are processed through various new processing techniques and methods by taking advantage of developments in science and technology. They become products ready for consumption by the public at home and abroad. (Charity, 2017) However, it should be remembered that most of the food industry products and world food technology do not apply the halal production system. This raises concerns that Indonesia is being flooded with food products and other products that contain or are contaminated with haram elements in the face of regional, international, and global free trade. In processing, storage, handling, and packaging techniques, additives and auxiliary materials that are harmful to health are often used or additives containing haram elements prohibited in Islam. Therefore, producers are required to have responsibility for the products they produce. (Ali, 2016)

The issue of certification and marking of halal products in the international trade system received the attention of many parties' attention to protect Muslim consumers. Around the world, but also as a strategy to face the challenges of globalization with the enactment of the free market system within the framework of ASEAN-AFTA, NAFTA, and the Economic Community. Europe, and the International Trade Organization (World Trade Organization). The international trade system has long recognized halal provisions in CODEX, supported by influential international organizations including WHO, FAO, and WTO. Even the halal lifestyle is currently sweeping the world. (Septiani \& Ridlwan, 2020) This is a symptom of a predominantly Muslim country with a nonMuslim majority population. (Faridah, 2019) Global companies are also currently implementing a halal system. Call it Japan Airlines, Singapore Airlines, Qantas, America Airlines, which provide a halal menu (Moslem meal). The need for halal products has also penetrated America, Australia, Japan, China, India, and Latin American countries.

In line with the demands of globalization, Law Number 33 of 2014 concerning Halal Product Guarantee (UUJPH) emphasizes the urgency of the halal-haram issue in the production chain, from business actors to consumers and is consumed by consumers. Intermediaries such as distributors, subdistributors, wholesalers, and retailers are also the role of intermediaries before reaching the end consumer. The enforcement of UUJPH aims to provide legal certainty to consumers (the wider community) for food products and other consumer goods. (Sayekti, 2014) As for business people, the existence of UUJPH can be used as a guide in processing, processing, producing, and marketing products to consumers and conveying information on halal products to the public.

As a derivative of the UUJPH, the Government also has issued Government Regulation (PP) Number 31 of 2019 and Regulation of the Minister of Religion (PMA) Number 26 of 2019 concerning the Implementation of Halal Product Guarantee and the Job Creation Law (Omnibuslaw) in the halal cluster as confirmation and correction of UUJPH No. 33/2014. 
However, the implementation of regulation generally cannot be separated from the implications that are difficult to predict if the regulation is made without prior empirical studies with related parties. Related parties (stakeholders), among others, are industry players within the scope of JPH, consumers, and of course, the Government itself and society at large. Fundamentally, as a technical translator of UUJPH, the PP and PMA mentioned above should have an applicative and adaptive nature, be effective and efficient. Therefore this research focuses on analyzing the problems in Law Number 33 of 2014, Government Regulation Number 31 of 2019, and PMA 26 of 2019 concerning JPH with the Regulatory Impact Assessment (RIA) analysis approach.

This research is field research with a descriptive qualitative approach. The data collected consists of primary data obtained through Focus Group Discussions (FGD) and is equipped with secondary data in the form of references by the research problem. The analytical method used is the Regulatory Impact Assessment (RIA). The regulations studied include the Halal Product Guarantee Act Number 33 of 2014, the Law on Halal Cluster Job Creation, Government Regulation on Halal Product Guarantee Number 31 of 2019. Regulation of the Minister of Religion (PMA) Number 26 of 2019 concerning the Implementation of JPH so that the UUJPH can be optimal and benefit all parties.

In the Guide Book on Regulatory Impact Assessment quoted by Nasokah (Nasokah, 2008), RIA is a systematic analysis and communication of various aspects in the establishment and implementation of a policy, both in the form of regulation and non-regulation, existing and new policies. RIA is also a method that systematically and consistently assesses the impact of government actions and communicates information to decision-makers. The accuracy of the RIA method in assessing and improving the quality of policies was also conveyed by the Minister of National Development Planning / Bappenas. (Alisjahbana, 2012)

Speculatively, the implementation of UUJPH at this time could have uncontrollable negative impacts. Still, it is also a certainty that it will positively impact Muslim consumers who are confident that a product is halal, as shown by previous studies analyzing the implications of implementing UUJPH. call it like Bintan and friends. (Ariny $\&$ Nurhasanah, 2020), Istiqomah (Istikomah, 2019), Abd. Rohman F(Abd. Rohman Fahruddin, 2019) and others. This research is also different from previous research, which analyzed UUJPH from a regulatory perspective. Panji Adam's research (Agus, 2017) talks about the position of halal certification in the national legal system to protect consumers in Islamic law, which focuses more on formal issues as a regulation. Other researchers Warto and friends (Warto et al., 2019), highlight the problem of the meaning and use of legal language with the istinbath approach, which aims to simplify the appropriateness of implementing JPH Law. Nidya Waras Sayekti revealed the advantages and disadvantages of UUJPH based on a descriptive conceptual institutional perspective. (Sayekti, 2014) Likewise, with Panji's research. (Agus, 2017) 


\section{Literature Review}

\section{Halal Product Guarantee Law (UUJPH)}

The term halalan thoyyiban (halal and good)(Q.S. Al-Baqarah: 168, n.d.) It is necessary to be effectively and operationally informed to the public, accompanied by adequate facilities and infrastructure. Therefore, one of the essential means of guarding halalan thayyiban is the presence of an established, central, humanist, progressive, accommodative, and non-discriminatory legal institution, namely the presence of the Halal Product Guarantee Law.

Several factors underlie the importance of UUJPH, among others, first, various existing laws that regulate or are related to halal products have not provided legal certainty and legal guarantees for consumers to be able to consume halal products, so that people have difficulty distinguishing between products halal and haram products. Also, the regulation of its products is still very limited in terms of only food and does not include drugs, cosmetics, biological chemical products, or genetic engineering. Second, there is no legal certainty to which institution the State is involved in guaranteeing halal products. The existing system has not confirmed the authority, duties, and functions of the implementation of JPH, including its coordination. Third, distribution and products in the domestic market are increasingly difficult to control due to increased food technology, technological engineering, biotechnology, and biological chemical processes. Fourth, Indonesian halal products do not have official halal standards and marks (national halal standards) set by the Government. So far, only the halal standards and logos from the Indonesian Ulema Council are valid and have not been officially established by the State. Fifth, the information system for halal products is not by the public's level of knowledge and needs regarding halal products.

UUJPH can be referred to as the formalization of Islamic law, which enters and permeates national law through the legislative process, as is the case with earlier Islamic law such as the Zakat Law, the Marriage Law, the Waqf Law, and the Hajj Organizing Law. Law on Religious Courts, Law on Islamic Banking, and so on, although it is not directly mentioned that Islamic law is Islamic law. This kind of thing can be understood considering the problems that continue to grow and become more complex according to the times. Indonesia is a country characterized by a religious society and having strong religious beliefs that influence its adherents' norms, values, culture, and behavior. The Constitution of the Republic of Indonesia recognizes this religiosity as stated in Article 29 of the 1945 Constitution, which is based on Divinity.

\section{Halal Product Guarantee Agency (BPJPH)}

Law Number 33 of 2014 concerning Halal Product Guarantee (UU-JPH) supervises and fosters various halal regulations that have been scattered in various laws and regulations. On the other hand, UUJPH can be called the legal umbrella (umbrella act) for regulating halal products. The Halal Product Guarantee (JPH) in this law covers various aspects, not only medicine, food, and cosmetics but wider than that to cover chemical products, biological products, genetically modified products, and consumer goods that are used, used, or utilized. By the 
community.

The regulation also covers halal products from upstream to downstream. Halal Product Processes are defined as a series of activities to ensure the halalness of a product, including the provision of materials, processing, storage, packaging, distribution, sales, and presentation of products. (UU Nomor 33 Tahun 2014, 2014). This aims to provide comfort, security, safety, and certainty of the availability of halal products for the public in consuming and using the products and increasing added value for business actors to produce and sell their products. The technical halal product guarantee is then translated through the certification process. Previously halal certification was voluntary, while UUJPH was mandatory. Therefore, all products that enter circulation and are traded in the territory of Indonesia must be halal certified. (UU Nomor 33 Tahun 2014, 2014) This is the main differentiator from the previous legislative products. Later, the person in charge of the halal guarantee system will be carried out by the Government. The Minister of Religion will organize by forming a JPH Organizing Body (BPJPH), which is domiciled under the minister of religion's responsible. BPJPH has the following authority (1) Formulating and stipulating JPH policies; (2) Establishing JPH norms, standards, procedures, and criteria; (3) Issue and revoking Halal Certificate and Halal Label on Products; (4) Registering the Halal Certificate for foreign products; (5) To conduct socialization, education, and publication of Halal Products; (6) Accrediting LPH (Halal Inspection Agency); (7) Registering the Halal Auditor; (8) Supervise JPH; (9) to foster Halal Auditor; and (10) Cooperating with domestic and foreign institutions in the field of organizing JPH.
In exercising the authority, BPJPH collaborates with the Ministry and related institutions, the Halal Inspection Agency (LPH and the Indonesian Ulema Council (MUI). Cooperation between BPJPH and $\mathrm{LPH}$ is carried out for inspection and product testing. Cooperation between BPJPH and MUI is carried out in the form of certification. Halal Auditor, determination of product halalness, and LPH accreditation. To assist BPJPH in conducting inspection or testing of halal products, the Government and the public can establish LPH. The requirements for establishing $\mathrm{LPH}$ include: (1) Has its own office and equipment; (2) Has accreditation from BPJP; (3) Having halal auditors of at least 3 (three) people; and (4) Owning a laboratory or cooperation agreement with other institutions that have laboratories.UUJPH opens opportunities for other institutions besides LPPOM MUI to open LPH. Islamic organizations that have integrity at central and regional levels, Islamic foundations, Government, state-owned enterprises, and state university campuses that have scientific capabilities in the food sector can be included in implementing and providing halal products for Muslim consumers in Indonesia.

\section{Regulation on the Enforcement of Mandatory Halal Certification}

UUJPH mandates that BPJPH must be formed no later than 3 (three) years since this law is promulgated. The implementing regulations for this law must be stipulated within 2 (two) years from the time this law is promulgated. Government Regulation on Halal Product Guarantee No. 31 of 2019 and Regulation of the Minister of Religion (PMA) No. 26 of 2019 concerning Implementation of Halal Product Guarantee have also been 
enacted. The obligation to certify halal for products originating from the territory of Indonesia shall take effect 5 (five) years since this law is promulgated. But then, for PMA No. 26 of 2019 that 17 October 2019 is the start of an era of mandatory product halal certification. Before the comprehensive halal certification obligation is by the scope of the UUJPH, the types of halal-certified products are regulated in stages; namely, the industrial group that is subject to the first phase of obligation is the food and beverage industry.

\section{Regulatory Impact Analysis (RIA)}

Regulatory impact analysis is an important tool that links regulatory quality, good governance, and economic development. Also, public participation (stakeholders) can increase transparency, build trust, and reduce regulatory risk. So that this can be said to be the lowest cost solution in helping reduce the cost of implementing regulations for regulators. In the preparation of legal products, it is more legal, namely emphasizing the suitability and compliance with higher levels of legislation but does not consider the participation of policymakers and public participation. In this case, a unique instrument is needed for policymaking, especially in policy research.

The RIA is a fundamental tool to assist the Government in assessing the impact of regulation. The RIA is used to test and measure the possible benefits, costs, and impacts of new or existing regulations. The RIA aims to provide a detailed and systematic assessment of the potential impact of new regulations to assess whether there is a possibility that the regulations can achieve their intended objectives. The need for an RIA arises because regulation generally has many impacts that are difficult to predict without a detailed study and consultation with affected parties. From this perspective, the main objective of the RIA is to ensure that regulation will improve people's welfare from the point of view that the benefits will outweigh the costs.

RIA has ten basic question standards, which are standards set by the OECD to formulate and implement better regulations. Like the standards in ISO 9001 used to establish quality management system standards, the RIA standard focuses on improving the regulatory process to achieve the goal of improving regulatory quality. (OECD, 2005) These standards are not intended to improve the management process but are expected as a policy instrument to achieve a regulatory quality level that can accommodate all stakeholders. The ten lists of questions in the RIA methodology are as follows: (1) Is the problem correctly defined? (2) Was the government action correct? (3) Is the existing regulation the best for the Government's move? (4) Is there a legal basis for regulation? (5) How many levels of government bureaucracy are involved in coordinating this regulation? (6) Are existing regulations worthwhile relative to the costs? (7) Is the distribution of the impact transparent in the community? (8) Are the regulations clear, consistent, understood, and accessible to users? (9) Do all interested parties have the same opportunity to share their views? (10) How can regulatory compliance be achieved?

The stages in the RIA design process systematically analyze and communicate the impact of the new regulations based on the OECD version, namely (OECD, 2008): (1) Formulate the problem. (2) Identify goals. (3) 
Devise alternatives. (4) Benefit and cost analysis. (5) Public consultation. (6) Choose the best alternative. (7) Implementation strategy. The analytical methods often used in analyzing the RIA document are (1) Soft benefit-cost analysis and integrated analysis. (2) Cost-effectiveness analysis. (3) Partial analysis

\section{Tabel 1.}

Ten Question in Regulatory Impact Analysis

\section{Risk Assessment and Uncertainty Analysis}

The ten-question standards in the RIA are standard standards set by the OECD to formulate and implement better regulations. This question is not to improve the management process. Still, it is hoped that it can achieve a level of regulatory quality that can accommodate all stakeholders as a policy instrument. Ten questions and answers are presented in Table 1.

\begin{tabular}{cl}
\hline No & \multicolumn{1}{c}{ Question } \\
\hline 1. & $\begin{array}{l}\text { Whether the problem is } \\
\text { correctly defined? }\end{array}$ \\
2. Is the Government's action \\
right?
\end{tabular}

3. Whether the existing regulations are the best for government steps?

4. Is there a legal basis for regulation?

5. How many levels of government bureaucracy are involved in coordinating this regulation?

6. Are the existing regulations useful, compared to the costs?

7. Is the distribution of the impact transparent in the
Answer

By the contents of UUJPH No. 33 of 2014, PP No. 31 of 2019 concerning JPH, and PMA No. 26 of 2019 concerning the implementation of JPH, problem identification has been defined correctly.

The Government's action is right, stipulating PP No. 31 of 2019 and PMA No. 26 concerning JPH to guarantee and protect consumers for halal products as well as creating healthy and fair business competitiveness because halal products are consumed by almost all people at large, especially Muslim communities in Indonesia and the world in general.

PMA number 26 of 2019 concerning the implementation of JPH is one of the best alternatives from the Government.

Yes, by the Halal Product Guarantee Law No. 33 of 2014 and Government Regulation No. 31 of 2019 concerning JPH.

The bureaucracy involved includes (i) Ministry of Religion, (ii) Ministry of Health, (iii) Ministry of Foreign Affairs, (iv) Ministry of Research Technology and Higher Education, (v) Ministry of Finance, (vi) Ministry of Communication and Informatics, ( vii) National Police of the Republic of Indonesia, (viii) Food and Drug Administration, (ix) National Standardization Agency, (x) National Accreditation Committee and (xi) Indonesian Ulema Council.

Further studies are needed regarding the benefits that will be obtained compared to the costs that will be incurred by the Government, considering that the nature of halal certification is mandatory, while the largest business actors are in the MSME sector, amounting to 60 million who need subsidies to comply with UUJPH.

It must be transparent so that the implementation of this regulation can still be regulated, supervised, and controlled. 
community?

8. Are the rules clear, It is clear and must be equally accessible to all Indonesian consistent, understood, and people. accessible to users?

9. Are all parties who concerned have the same opportunity to convey their views?

10. How regulatory compliance Gradually the application of halal certification obligations is by can be achieved?

All parties (stakeholders) have the same opportunity to express their opinions.

the urgency and readiness of the industry, related to the possible impact it will cause.

\section{The Method, data, and analysis}

This study examines ways to save MSMEs affected by the Covid-19 pandemic to maintain the stability of the national financial system by using a qualitative descriptive literature study. Qualitative research is a method designed to uncover temporary life issues that will develop in the field-research data obtained from literature study and interviews.

The literature study method is a series of activities related to collecting library data, reading, taking notes, and processing research materials (Kartiningrum, 2015: 26). Data are collected from various sources such as textbooks, journals, articles, literature reviews, and statistical data discussed in this field. According to Bungie (2011: 20), Literature study is one of the data collection methods used in social research to explore data.

Interviews were conducted with 100 MSMEs spread across Semarang, Demak, and Kendal regencies carried out between September and December 2020. The interview is a dialogue carried out by two parties, namely the interviewer and the interviewee, with a specific purpose for writing. (Moleong, 2017: 186). This study uses semi-structured interviews, which are more flexible than structured interviews (Sugiyono, 2018). The purpose of this interview was to find out more open problems, where the interviewees were asked about the problems faced by their MSMEs due to the Covid-19 pandemic. Data analysis begins with relevant research findings and reviews previous research to assess the problem. Important and relevant parts of the research topic are recorded, including the data source.

\section{Result and Discussion}

\section{RIA Analysis}

RIA's systematic process in analyzing and communicating the existing impact of new regulations includes the following:

\section{Background of the Paper}

The formulation of the problem which is expected to be resolved with the existence of Regulation of the Minister of Religion of the Republic of Indonesia Number 26 concerning JPH, among others:

a. Are all the supporting facilities for implementing Regulation of the Minister of Religion of the Republic of Indonesia No. 26 of 2019 ready? 
b. Whether the Regulation of the Minister of Religion of the Republic of Indonesia No. 26 of 2019 can protect and balance the interests of all stakeholders (society, industry, and Government)?

c. Can through the Regulation of the Minister of Religion of the Republic of Indonesia number 26 of 2019 protect consumers from the halalness of the products consumed, ease in processing halal certification for business actors, and create healthy and fair business competitiveness.

\section{Purpose Identification}

The objectives to be achieved with the enactment of Regulation of the Minister of Religion Number 26 of 2019 are to protect consumers from the halalness of the products consumed, ease in processing halal certification for business people, and create healthy and fair business competitiveness.

\section{Alternative Solutions Problems}

Alternative solution goals to solve the problem, namely:
a. Continuing Regulation of the Minister of Religion of the Republic of Indonesia Number 26 of 2019
b. I am postponing the Regulation of

the Minister of Religion of the Republic of Indonesia Number 26 of 2019 by correcting the existing gap.

c. Cancel Regulation of the Minister of Religion of the Republic of Indonesia Number 26 of 2019.

\section{Benefit and Cost Analysis}

Benefit and cost analysis is used to evaluate economic resources so that these scarce resources can be used efficiently, including the APBN. Cost-benefit analysis or CBA (Cost-Benefit Analysis) is an approach to policy recommendations that allow analysts to compare and recommend a policy by calculating the total cost in money and the total profit in money. Cost-benefit analysis can also be defined as a technique used to compare the various costs associated with an investment with the expected benefits. Tangible and intangible factors must be calculated and accounted for. Cost-benefit analysis is used to determine whether an investment is feasible and provides a basis for comparison between projects/investments to see which options provide more significant benefits than costs. Analysis of the benefits and costs of implementing the mandatory PMA RI No. 26 of 2019 is presented in Table 2.

Table 2.

Analysis of the Benefits and Costs of Implementing PMA No. 26 of 2019

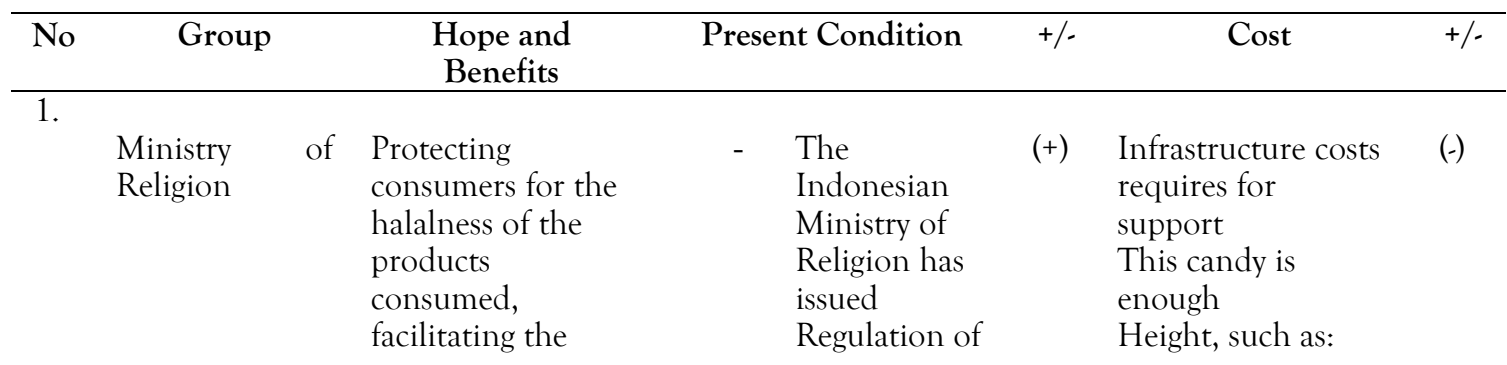




processing of halal
certification for
business actors,
and creating
healthy and fair
business
competitiveness

2 National Accreditation Committee (KAN)

\section{The Halal}

Inspection Agency (LPH) supports the enactment of PMA No. 26 of 2019 the Minister

of Religion

(PMA) no 26

of 2019

concerning

the

Implementati on of Halal

Product

Guarantee, which will be effective starting on 17 October 2019

- The

Indonesian Ministry of Religion has issued the Minister of

Religion Decree (KMA)

Number 982 of 2019 concerning Halal Certification Services

- The Ministry of Religion of the Republic of Indonesia through the Decree of the Head of BPJPH No. 177 of 2019 has established LPPOM MUI as the $\mathrm{LPH}$.

$\begin{array}{llr}\text { There is no } & \text { It is necessary to } \\ \text { LPH } & \text { prepare the LPH if } \\ \text { accredited } & \text { the LPH comes } \\ \text { according to } & \text { from } & \text { Government. It } \\ \text { the UUJPH } & \text { requires a fee to } \\ \text { standard } & \text { prepare a halal } \\ \text { criteria by } & \text { auditor and } \\ \text { BPJPH and } & \text { laboratory } \\ \text { MUI } & \end{array}$

- Regional BPJPH offices - BPJPH HR in all provinces

- National ICT infrastructure 


\section{Local \\ Government,} BPOM,

Quarantine, Police, etc.
Regional

Government,

Quarantine, BPOM, Police and supervisory agencies others according to

respective main tasks and functions support enforcement Ministerial regulation Republic Religion Indonesia Number 26 years 2019 associated with supervision Domestic Industry Most of the industries (industry and UMKM) apply Regulation of the Minister of Religion Number 26 of 2019 to create healthy and fair
that have independently owned halal certificates are medium and large industries, while small industries and MSMEs mostly do not have halal certificates

- $\quad$ There are only

3 test

laboratories

for the halal

scope.

However, a test laboratory accredited by KAN and can test parameters within the scope of UUJPH according to the needs of the MUI fatwa only has 1 (one) Test Laboratory, namely the LPPOM MUI Laboratory. Lack of budget and resources human in Local Government in the main tasks and functions of monitoring circulating goods (Saputra, 2015). infrastructure

infrastructure
(-) $\quad$ A fee is required
in team building goods supervisor in circulation involving all related agencies

(-) The scope of $\mathrm{UUJPH}$ is very broad and is mandatory for all business actors to certify halal. Large subsidies are required from the Government to be 


$$
\text { competitiveness }
$$

5

Consumers can
acquire halal
products and
the quality is
guaranteed

independently, most of them are assisted by local governments or related agencies.

By the objectives of the Ministerial Regulation, that the purpose of implementing this PMA is to protect consumers on the halalness of the products consumed, to facilitate halal certification for business actors, and to create healthy and fair business competitiveness. able to help MSME

products obtain

halal certificates.

(+) This policy is unlikely to have a significant effect on product prices from large industries at the consumer level.

As for the price at the SME level industry Most likely will affect the price of the product. So that for SMEs it has a negative impact, especially if there are no more subsidies from the Government.

The number of subsidies to fulfill the mandatory obligations for halalcertified products is very large when referring to the number of SMEs in Indonesia reaching 60 million. If it is assumed that food and beverage SMEs are 50 percent, the amount of subsidies is still very large.

\section{Public Consultation}

Consultation to obtain the best alternative by involving stakeholders. The data was extracted from the Focus Group Discussion (FGD) held by MASTAN, BPKN, and KNKS. Joint Meetings involving the community, industry, and related associations and the
Government. The consultation was carried out because it was based on the principle that:

a. Strategic policy-making involves all affected parties in an equal process of negotiation and consultation.

b. The involvement of all affected 
parties can improve the quality of benefits received by the public due to the policy.

\section{Choose the Best Alternative}

Based on the RIA results regarding the implementation of regulations, they refer to the Regulation of the Minister of Religion of the Republic of Indonesia Number 26 of 2019, namely by delaying its implementation. This regulation is to fill the gap between current conditions and ideal conditions. This is because the benefit is smaller than the cost that the Government must incur to achieve the ideal condition, which is $2: 10$.

The postponement of implementing the Regulation of the Minister of Religion is to achieve ideal conditions. However, the comparison is still extensive, especially in the infrastructure for halal certification activities and the completeness attributes such as halal standards, LPH accreditation standards, and laboratories. Therefore, it is hoped that later this regulation can achieve the expected goals.

For current conditions, this delay does not affect the guarantee of halal products in Indonesia because MUI and LPPOM MUI have implemented halal-related regulations in the Food Law, Consumer Protection Law, Animal Husbandry Law, and the SPK Law quite well. In addition, LP-POM MUI performs halal certification activities using the online system (CEROL SS-23000). This activity helps the halal certification process for domestic and foreign business actors. MUI has accredited Foreign Halal Institutions. The LPPOM MUI halal laboratory has been accredited with ISO 17025, halal standards as a derivative of the MUI fatwa have been documented in the HAS23000 standard book for UUJPH.
This delay provides an opportunity for all stakeholders, especially the Government, to prepare themselves for better consolidation within the framework of Law number 33 of 2014 concerning Halal Product Guarantee. Fulfilling the gaps needed to support this regulation are as follows:

a. Establish halal standards and measurement standards for halal test parameters as a reference for halal certification activities for business actors, LPH, and accreditation bodies.

b. Halal Inspection Agency (LPH) that meets the criteria of UUJPH

c. a Sufficient number of accredited and Halal Testing Laboratories to support halal certification activities at the national level. Test laboratories that KAN has not accredited provide test results with the KAN logo on the potential to violate Law Number 20 of 2014. LPH, which carries out certification activities and provides the KAN logo but has not yet received accreditation for the intended scope, can violate Law Number 20 of 2014 Article 70, which can be sentenced to imprisonment of 5 (five) years or a maximum fine of Rp. 35,000,000,000.00 (thirty five billion rupiah) (State Secretariat, 2014). The Conformity Assessment Agency (LPK, read LPH in UUJPH) must be accredited by KAN. Because according to international regulations, LPKs that have not been accredited cannot guarantee the validity of the test results (testing labs), and the validity of the issued certificates (LSH).

d. Legislation, it is necessary to prepare 
a technical guideline for LPH in making a certification scheme. The treatment for imported products is not differentiated from domestic products by using a certification scheme based on ISO17065.

e. Business people, it is necessary to assist SMEs in meeting regulatory requirements. This regulation needs to be disseminated to all industries that have not received a halal certificate. The goal is to have sufficient time to prepare to meet the regulatory requirements. It is mainly related to compliance with the Halal Assurance System (SJH), the halal certification process, registration of halal products, manufacture of labeled packaging. Halal and marketing of products with packaging marked with halal.

f. The supervision process needs to be coordinated and synchronized with the regulatory program for the supervision of halal-labeled products between the regulator and the supervisory agency. This can be done at the central or regional level. The goal is to support the Minister of Religion of the Republic of Indonesia Number 26 of 2019. One of the supervisions is focused on SME products such as home industry products.

The postponement of the enactment of the Regulation of the Minister of Religion of the Republic of Indonesia Number 26 of 2019 will not have much effect on the trade-in halal products in Indonesia because of the following matters: a. The domestic halal product industry from medium to large Indonesian companies has controlled the domestic market share with a percentage value of $80 \%$ of the domestic market share (Kadin, 2014).

b. LPPOM MUI, as an Indonesian Halal Certification Agency in the scheme of Law Number 20 of 2014 concerning Standardization and Conformity Assessment, has received accreditation from KAN in the DPLS21 scheme, ISO 17065: 2012, and the UAE UEA scheme. S 2055-2 means acceptance of national halal products certified by MUI is becoming more widespread in Gulf countries and OIC. This is interpreted to help increase trade in national halal products.

c. The acceptance of the MUI Halal Standard, namely HAS23000, has also been widely accepted by 44 foreign Halal Institutions from 26 countries

\section{Implementation Strategy}

The final stage of the RIA analysis is to plan a policy implementation strategy. Based on this, an implementation strategy is made at this stage. The best alternative needs to be made a Ministerial Regulation to postpone the existing Ministerial Regulation followed by making improvements that have been submitted. The results of RIA's analysis of the enactment of the Regulation of the Minister of Religion of the Republic of Indonesia Number 26 of 2019, provide evidence that it can be used as a fundamental tool to assist the Government in assessing the impact of a regulation. 


\section{Conclusion}

Based on the results of the analysis and discussion, it can be concluded that with the Risk Assessment and Uncertainty Analysis method, the Regulation of the Minister of Religion of the Republic of Indonesia Number 26 of 2019 has a cost and benefit assessment with a ratio of positive and negative values of $2: 10$. The ratio of negative values is mainly in the Government group. Regulation of the Minister of Religion of the Republic of Indonesia Number 26 of 2019 is less effective if it is still enforced by the stipulated provisions, starting on 17 October 2019. In this regard, the Government, through the Ministry of Religion, can postpone the enactment of the Regulation of the Minister of Religion of the Republic of Indonesia Number: 26 of 2019 to fix the gap between current conditions and ideal conditions and not hinder the business climate for domestic trade and exports of national halal products.

\section{Suggestion}

This research certainly has not thoroughly analyzed comprehensively how the implementation of the UUJPH in society, how its implications are for the parties concerned, what are the implications for the position of halal law itself, and how the political, economic, legal, social, and cultural impacts of halal in Indonesia. Moreover, apart from time constraints and other technical limitations, the Work Creation Law (Omnibuslaw) on the halal cluster is also a revision and confirmation of Law Number 33 of 2014 concerning Halal Assurance. However, the Indonesian House of
Representatives just passed on 5 October 2020, so it is not enough to be used as relevant study and analysis material.

\section{References}

Abd. Rohman Fahruddin. (2019). Implementasi Pengelolaan Makanan Halal Di Indonesia. At-Tasharruf; Jurnal Kajian Ekonomi Dan Bisnis Syariah, 1(1), 37-46.

https://doi.org/10.32528/at.v1i1.2488

Agus, P. A. (2017). Kedudukan Sertifikasi Halal Dalam Sistem Hukum Nasional Sebagai Upaya Perlindungan Konsumen Dalam Hukum Islam. Amwaluna: Jurnal Ekonomi Dan Keuangan Syariah, 1(1), 150-165.

https://doi.org/10.29313/amwaluna.v1 i1. 2172

Ali, M. (2016). Konsep Makanan Halal dalam Tinjauan Syariah dan Tanggung Jawab Produk Atas Produsen Industri Halal. AHKAM: Jurnal Ilmu Syariah, 16(2), 291-306.

https://doi.org/10.15408/ajis.v16i2.44 59

Alisjahbana, A. S. (2012). Pengembangan Dan Implementasi Metode Regulatory Impact Analysis (RIA) Untuk Menilai Kebijakan (Peraturan Dan Non Peraturan) Di Kementerian Ppn/Bappenas. Biro Hukum Kementerian PPN/Bappenas. http://jdih.bappenas.go.id/monografi/ detailmonografi/1897

Ariny, B. D., \& Nurhasanah. (2020). Dampak Positif Undang-Undang Nomor 33 Tahun 2014 Tentang Jaminan Produk Halal Dalam Menciptakan Sistem 
Jaminan Produk Halal Di Indonesia. Syarie: Jurnal Pemikiran Ekonomi Islam, 3(2), 198-218. https://staibinamadani.ejournal.id/Syarie/article/view/204/170 Charity, M. L. (2017). Jaminan Produk Halal Di Indonesia. Jurnal Legislasi Indonesia, Vol.14(1), 99-107. https://ejurnal.peraturan.go.id/index.php/jli/iss ue/view/9

Faridah, H. D. (2019). Halal certification in Indonesia; history, development, and implementation. Journal of Halal Product and Research, 2(2), 68. https://doi.org/10.20473/jhpr.vol.2issue. 2.68-78

IBTimes.ID. (2020, April 8). Data Populasi Penduduk Muslim 2020: Indonesia Terbesar di Dunia. PT Litera Cahaya Bangsa. https://ibtimes.id/datapopulasi-penduduk-muslim-2020indonesia-terbesar-di-dunia/

Istikomah. (2019). Peluang Dan Tantangan Implementasi UU JPH. At-Tasharruf; Jurnal Kajian Ekonomi Dan Bisnis Syariah, 1(1), 18-28. https://doi.org/10.32528/at.v1i1.2486

Nasokah, N. (2008). Implementasi Regulatory Impact Assessment (RIA) Sebagai Upaya Menjamin Partisipasi Masyarakat Dalam Penyusunan Peraturan Daerah. JURNAL HUKUM IUS QUIA IUSTUM, 15(3), $\quad 443-458$. https://doi.org/10.20885/iustum.vol15 .iss 3 .art5

OECD. (2005). Recommendation of the Council on Improving the Environmental Performance of Government. 5-6. https://legalinstruments.oecd.org/en/i nstruments/OECD-LEGAL0278\#mainText

OECD. (2008). Building an Institutional Framework for Regulatory Impact Analysis (RIA). Building an Institutional Framework for Regulatory Impact Analysis (RIA). https://doi.org/10.1787/97892640500 13-en

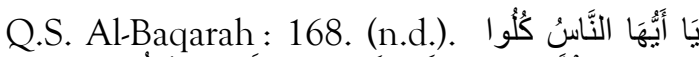

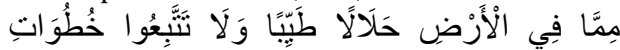

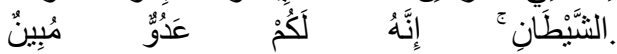
https://tafsirq.com/2-al-baqarah/ayat168

Sayekti, N. W. (2014). Jaminan Produk Halal dalam Perspektif Kelembagaan. Jurnal Ekonomi Kebijakan Publik, 5(2), 193-209. https://doi.org/10.22212/jekp.v5i2.84

Septiani, D., \& Ridlwan, A. A. (2020). The Effects of Halal Certification and Halal Awareness on Purchase Intention of Halal Food Products in Indonesia. Indonesian Journal of Halal Research, 2(2), 55-60.

https://doi.org/10.15575/ijhar.v2i2.66 57

UU Nomor 33 Tahun 2014. (2014). Tentang Jaminan Produk Halal. BPJPH.

Warto, W., Rofiq, A., \& Mashudi, M. (2019). Peranan Kaedah-Kaedah Fundamental Kebahasaan Dalam Penetapan Produk Halal. Indonesia Journal of Halal, 2(1), 10. https://doi.org/10.14710/halal.v2i1.43 18

http://journal.walisongo.ac.id/index.php/JDMHI/index DOI: http://dx.doi.org/10.21580/jdmhi.2021.3.2.9345 